\title{
Haematological and obstetric aspects of antenatal diagnosis of $\beta$-thalassaemia: experience with 200 cases
}

\author{
A CAO, M FURBETTA, A ANGiUS, A XIMENES, C ROSATELLI, T TUVERI, \\ M T SCALAS, A M FALCHI, G ANGIONI, AND F CAMINITI
}

From the 2nd Pediatric Clinic, and Department of Obstetrics and Gynecology, University of Cagliari, Cagliari, Sardinia

SUMMARY The results of 200 antenatal diagnoses in pregnancies at risk for homozygous $\beta$-thalassaemia, carried out on fetal blood samples obtained by placental aspiration in the second trimester, are described. Globin chain synthesis in the fetuses was measured by means of ${ }^{3} \mathrm{H}$-leucine incorporation and separation of the chains on carboxy-methyl-cellulose columns. Fetal red cell enrichment was performed by $\mathrm{NH}_{4} \mathrm{Cl}-\mathrm{NH}_{4} \mathrm{HCO}_{3}$ differential lysis of maternal cells or anti-i differential agglutination. Sufficient fetal blood for analysis was obtained in $97.5 \%$ of the cases. The overall fetal loss rate was $6.5 \%$, but it declined from $10 \%$ in the first consecutive 100 cases to $3 \%$ in the last 100 cases. Fetal loss was the result of early or late intrauterine death or spontaneous abortion. Forty-two homozygous fetuses had no $\beta$-chain synthesis and one had a very low $\beta / \gamma$ ratio $(0.005)$. Of the pregnancies, 37 were terminated at parental request and four aborted spontaneously. Absence of $\beta$-chain radioactivity was confirmed in 12 abortuses with suitable cord blood samples for analysis. Two pregnancies with homozygous fetuses were not terminated, as one member of each couple was a devout Catholic. As expected, both infants developed Cooley's anaemia. Follow-up of the 146 infants, diagnosed in utero as non-homozygotes, showed cerebral palsy in one and a small cutaneous needle injury in three. None of these developed homozygous $\beta$-thalassaemia. Even $\beta$-thalassaemia trait with a $\beta / \gamma$ ratio of $0.046 \pm 0.012$ can be distinguished from normal, showing a $\beta / \gamma$ ratio of $0.086 \pm 0.019$ with a high degree of certainty.

Through advances in fetal blood sampling ${ }^{1-5}$ and development of biochemical methods for analysis of globin chains or haemoglobin synthesis of fetal reticulocytes, ${ }^{6-9}$ in the last few years prenatal diagnosis of homozygous $\beta$-thalassaemia and other inherited haemoglobin disorders has been shown to be feasible and accurate. ${ }^{10-19}$

In many countries where thalassaemia is prevalent and there is no social or ethical attitude against termination of pregnancy, such as in Greece, Cyprus, and Italy, a great demand for antenatal diagnosis has arisen. Up to March 1980 at least 1100 pregnancies at risk, including our series, have been monitored in several centres around the world (Alter, 1980 , personal communication).

The main problems encountered in the early stages of development of this technology concerned

Presented in part at the Fourth Cooley's Anemia Conference, New York Academy of Sciences, New York, 21-23 May 1979.

Received for publication 24 April 1981 the fetal blood sampling with associated fetal loss and the analysis of placental samples containing low fetal red cell percentages. ${ }^{15}$

Here we report (1) the obstetric and haematological results of antenatal diagnosis in the first 200 consecutive pregnancies at risk for $\beta$-thalassaemia monitored in the Genetic Service of the 2nd Pediatric Clinic of Cagliari University, Sardinia, between May 1977 and November 1979, and (2) the follow-up observations carried out in the offspring of these pregnancies.

\section{Methods}

\section{SUBJECTS}

Two hundred and fifty-three couples at risk, either with previous affected children or identified by heterozygote screening, were counselled with particular emphasis on the early stage of development of this technology, the possibility of misdiagnosis or 
TABLE 1 Pregnancies monitored

Couples with previous affected offspring

Couples without previous

$\beta 0$-thalassaemia

$\boldsymbol{\beta}^{+}$-thalassaemia

Sickle cell $/ \boldsymbol{\beta}^{0}$-thalassaemia affected offspring
107

5

87

fetal blood sampling failure, and the risk of fetal loss (approximately 10\%). Of these. 200 decided on antenatal testing and 53 decided against, either because of ethical reasons or concern about possible complications. Of the 200 couples monitored, 113 had already had one or more affected children (retrospective diagnosis) and 87 had no affected children (prospective diagnosis) (table 1). The affected offspring had homozygous $\beta^{0}$-thalassaemia in 107 cases, homozygous $\beta^{+}$-thalassaemia in five cases, and sickle cell $/ \beta^{0}$-thalassaemia in one case. In the remaining couples with no affected offspring, both members were high $\mathrm{Hb} \mathrm{A}_{2} \beta$-thalassaemia carriers. The majority of these couples were probably at risk for $\beta^{0}$-thalassaemia, as this is by far the most common type of $\beta$-thalassaemia in Sardinia. ${ }^{20}$

The diagnosis of the $\beta$-thalassaemia carrier state was based on reduced MCV and MCH (Coulter Counter model S, Hileal, Florida) and increased Hb $\mathrm{A}_{2}$ levels (DE-52 microchromatography, according to Huisman et al $^{21}$ ). The thalassaemia type of the previous affected offspring was defined by globin chain synthesis analysis. ${ }^{22}$ Informed consent was obtained from each couple.

FETAL BLOOD SAMPLING

Fetal blood sampling was carried out by placental aspiration with a 20 gauge needle at 18 to 24 weeks' gestation after placental localisation with ultrasound (Picker Echoview model 80L), as described elsewhere. ${ }^{14}$

Before placental aspiration, maternal venous blood was drawn for reticulocyte count, fetal haemoglobin stain, and ${ }^{3} \mathrm{H}$-leucine incorporation. Fetal haemoglobin staining was repeated on a maternal blood sample within 7 hours of the procedure.

In the $17 \mathrm{Rh}$ negative mothers with $\mathrm{Rh}+$ fathers, anti-Rh globulins $(200 \mu \mathrm{g})$ were administered within 48 hours of the procedure, as it was not possible to carry out fetal red cell typing.

\section{CELL SIZING}

Samples containing blood-tinged amniotic fluid were collected in heparinised syringes and analysed immediately. Cell counts were performed with a Coulter Counter model ZBI. The presence of fetal red blood cells in the placental samples was rapidly

determined by red blood cell volume analysis with a Coulter C-1000 Channelyzer attached to a Coulter Counter model ZBI, as already described. ${ }^{10}$ To verify the results obtained, smears from the same samples were stained by the Betke-Kleihauer method $^{23}$ and the fetal red cell percentage determined.

\section{INCUBATION}

Placental samples were incubated with ${ }^{3} \mathrm{H}$-leucine as already described. ${ }^{10}$ An aliquot of maternal venous blood, drawn just before placental sampling, was treated in the same way.

\section{FETAL RED CELL ENRICHMENT}

Fetal red blood cells were concentrated by differential agglutination with anti-i serum (kindly provided by Dr Kan), according to Kan et al, ${ }^{14}$ or by $\mathrm{NH}_{4} \mathrm{Cl}$ $\mathrm{NH}_{4} \mathrm{HCO}_{3}$ differential lysis of maternal cells according to Boyer $e t a l^{24}$ and Alter et $a l^{25}$ with slight modifications, as already described. ${ }^{26}$

In two cases fetal red cell concentration was carried out by differential agglutination with antiAB serum. ${ }^{27}$

Lysate and globin preparation and CM-52 column radiochromatography were carried out by previously described methods. ${ }^{10}$

\section{DIAGNOSIS}

The radioactivity under each globin peak was integrated after subtraction of the residual baseline counts. The $\beta / \gamma$ globin chain synthesis ratios were obtained either in samples with 80 to $100 \%$ fetal red cells, original concentration or obtained after enrichment, or calculated by extrapolation when a sufficiently high fetal red blood cell concentration (less than $80 \%$ ) could not be obtained.

Extrapolation was made with at least three original placental samples or samples obtained in the anti-i purification steps with differing red cell percentages.

\section{HAEMATOLOGICAL FOLLOW-UP}

Globin chain synthesis analysis was carried out on cord blood of fetuses aborted with intra-amniotic $\mathrm{PGF}_{2} \alpha$-prostaglandin, whenever there were samples suitable for analysis.

Blood samples from newborn infants were tested by globin chain synthesis analysis and/or red cell indices determination (Coulter Counter model S) plus cellulose acetate, $\mathrm{pH} 8 \cdot 4$ (Helena Laboratories, Beaumont, Texas), and citrate agar gel, $\mathrm{pH} 6 \cdot 2$, electrophoresis. After 6 months the infants were restudied with the same tests plus $\mathrm{Hb} \mathrm{A_{2 }}$ (DE-52 microchromatography according to Huisman et $\mathrm{al}^{21}$ ) and $\mathrm{Hb} \mathrm{F}$ quantification. ${ }^{28}$ 


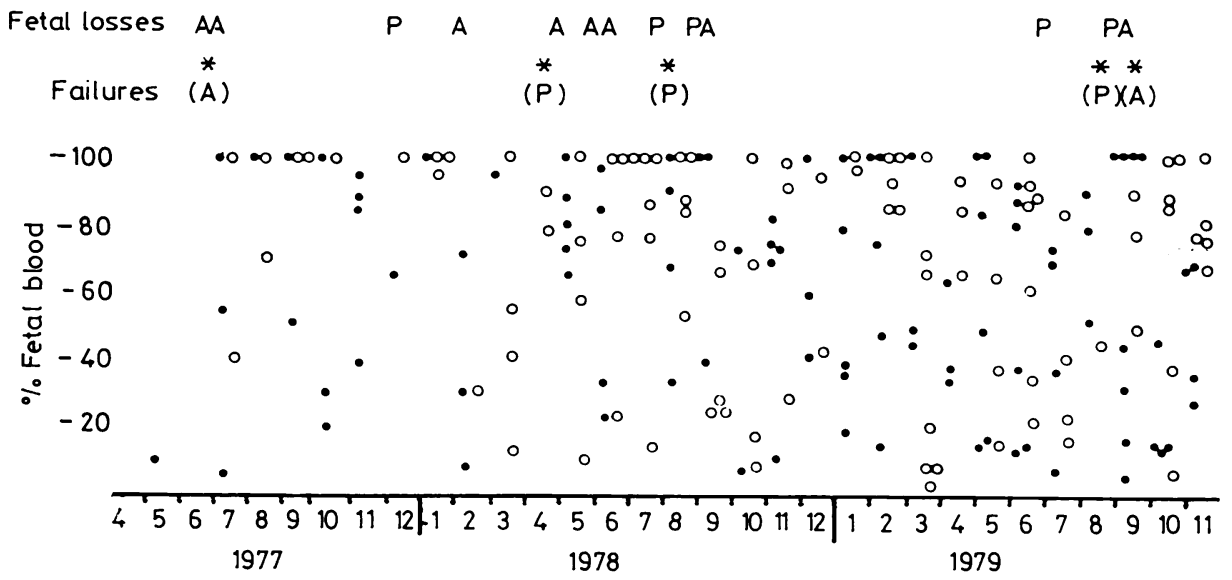

FIG 1 Results of fetal blood sampling by placentocentesis. $\bigcirc$ and A: anterior placenta; $\bullet$ and P: posterior placenta.

CLINICAL FOLLOW-UP

The course and outcome of pregnancies where a presumptive diagnosis of the non-homozygous state had been made were observed and followed. The infants born were examined at birth or at 6 and 12 months, or both.

\section{Results}

FETAL BLOOD SAMPLING

Sufficient fetal blood for analysis was obtained in 195 $(97.5 \%)$ of the 200 cases tested (fig 1).

The needle was inserted 1 to 4 times and from 2 to 85 small samples of blood-tinged amniotic fluid were obtained. Placental aspiration was repeated twice in 26 subjects and three times in nine with a oneweek interval between attempts (table 2).

TABLE 2 Results of fetal blood sampling by placental aspiration

\begin{tabular}{lrcc}
\hline & Total & $\begin{array}{c}\text { Anterior } \\
\text { placenta }\end{array}$ & $\begin{array}{c}\text { Posterior } \\
\text { placenta }\end{array}$ \\
\hline $\begin{array}{l}\text { No of pregnancies } \\
\text { monitored }\end{array}$ & 200 & 100 & 100 \\
Sufficient fetal blood & & & \\
$\quad$ obtained at 1st attempt & 160 & 79 & 81 \\
At 2nd attempt & 26 & 16 & 10 \\
At 3rd attempt & 9 & 3 & 6 \\
Failures & 5 & 2 & 3 \\
\hline
\end{tabular}

TABLE 3 Fetal cell percentages in placental blood samples

\begin{tabular}{lcll}
\hline & Total & $\begin{array}{l}\text { Anterior } \\
\text { placenta }\end{array}$ & $\begin{array}{l}\text { Posterior } \\
\text { placenta }\end{array}$ \\
\hline No of cases & 195 & 98 & 97 \\
With $100 \%$ fetal blood & 46 & 20 & 26 \\
With fetal blood between & & & 42 \\
$\quad 50$ and $100 \%$ & 81 & 39 & 29 \\
With fetal blood $<50 \%$ & 68 & 39 & \\
\hline
\end{tabular}

Fetal red cell counts and percentages varied from $4 \cdot 2 \times 10^{6}$ to $3 \times 10^{9}$ and from $3 \cdot 8$ to $100 \%$, respectively (fig 1). Fetal blood samples which were practically pure or with fetal cell percentages varying from 50 to $100 \%$ were obtained in 23 and $40.5 \%$ of the cases tested, respectively (table 3 ). There was a slightly higher success rate in posterior than in anterior placentas, as greater red cell percentages (table 3, fig 1) and volumes were obtained in the former.

In five pregnancies sufficient fetal blood for analysis could not be obtained. In two of these, already complicated by urinary infection, sampling was not repeated as there was a spontaneous abortion a few days after the first attempt. In one, the couple presented at 24 weeks' gestation, too late to have enough time for a second attempt. Another had only two attempts, as needling was too complicated because of placenta praevia and the presence of two large uterine fibromas. One case had three consecutive unsuccessful attempts with no defined cause.

FOLLOW-UP OF THE PREGNANCIES

Thirteen fetal losses occurred after sampling, eight involving the anterior placenta and five the posterior. The losses were the result of intrauterine death within 10 days of the procedure in two cases, after 10 days in six cases, and of spontaneous abortion in five, two having maternal urinary infection (table 4).

The minor complications observed were as follows: premature delivery (two cases), hemiplegic cerebral palsy (one case), needle injury in the buttock or thigh (three cases), fetomaternal transfusion with a fetal blood loss of approximately $120 \mathrm{ml}$ (one case). 
TABLE 4 Complications after fetal blood sampling by placentocentesis

\begin{tabular}{llll}
\hline & Total & $\begin{array}{c}\text { Anterior } \\
\text { placenta }\end{array}$ & $\begin{array}{c}\text { Posterior } \\
\text { placenta }\end{array}$ \\
\hline Major & & & \\
$\quad$ Intrauterine death & 2 & 1 & 1 \\
$\quad$ Within 10 days* & 6 & 5 & 1 \\
$\quad$ After 10 days & 5 & 2 & 3 \\
Spontaneous abortion & 2 & & \\
Minor & 1 & & \\
Premature delivery & 1 & & \\
Spastic palsy & 3 & & \\
Fetomaternal transfusion & & \\
Cutaneous needle injury & 3 & \\
\hline
\end{tabular}

*After the procedure

TABLE 5 Fetal blood sampling failure and fetal loss after placentocentesis: early versus late experience

\begin{tabular}{lrr}
\hline No of consecutive monitored pregnancies & $1-100$ & $101-200$ \\
Fetal loss rate & $10 \%$ & $3 \%$ \\
Failure rate & $3 \%$ & $2 \%$ \\
\hline
\end{tabular}

There was a steady decline of both fetal blood sampling failure and fetal loss rates from the beginning to the later stages (table 5).

FETAL RED CELL ENRICHMENT

Fetal red cell enrichment was carried out in all the samples, even those slightly contaminated with maternal cells. In 61 cases the enrichment was performed with anti-i differential agglutination of fetal cells and in 94 cases with $\mathrm{NH}_{4} \mathrm{Cl}-\mathrm{NH}_{4} \mathrm{HCO}_{3}$ differential lysis of maternal cells. In two cases, already reported, ${ }^{27}$ with maternal blood group $\mathrm{O}$ and paternal blood $\mathrm{AB}$, differential agglutination with anti-AB serum was carried out.

In many cases both the enrichment procedures were used for checking the haematological results obtained with Ørskov lysis, as has already been reported. ${ }^{26}$

In some cases in which a satisfactory fetal cell concentration with Ørskov lysis was not obtained, the same samples were successfully enriched with anti-i differential agglutination.

The samples enriched with anti-i serum had fetal red cell percentages varying from 6.7 to $92 \cdot 1 \%$ and counts from $4.2 \times 10^{6}$ to $725 \times 10^{6}$. The final concentration was $26 \cdot 7$ to $\sim 100 \%$.

The samples enriched by differential lysis of maternal cells had fetal red cell percentages and counts ranging from $3 \cdot 8$ to $89 \cdot 3 \%$ and from $5 \cdot 10^{6}$ to $113 \cdot 10^{7}$, respectively. The final concentrations were approximately $100 \%$ in all but 27 cases and the recovery was $20 \cdot 2$ to $100 \%$. In the 27 cases with partial enrichment, the final red cell percentages varied from 42.9 to $96.9 \%$.

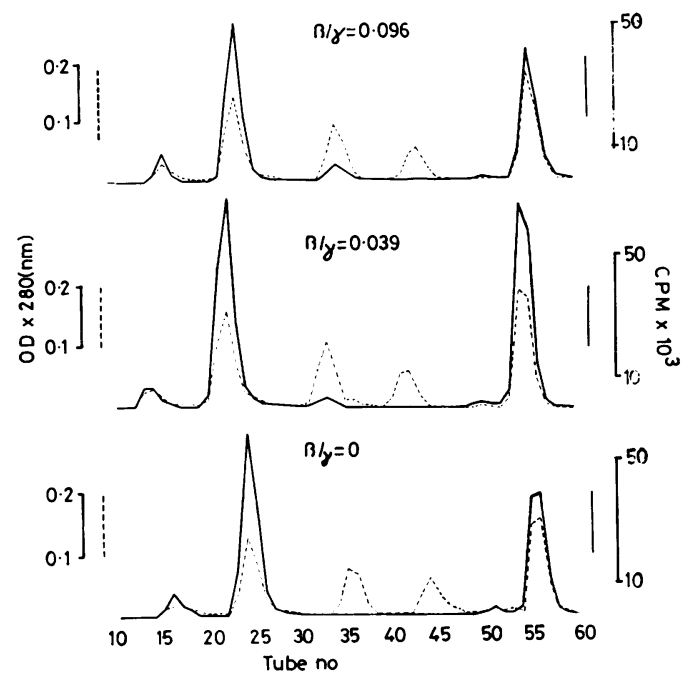

FIG 2 CM-cellulose radiochromatography of globin chains from three representative fetuses: top, normal; middle, heterozygous; bottom, homozygous.

From left to right, $\gamma, \beta^{\mathrm{A}}, \beta^{\mathrm{s}}$, and $\alpha$ chains.

\section{HAEMATOLOGICAL RESULTS}

Fig 2 shows representative chromatograms of normal, heterozygous, and homozygous fetuses. The $\beta / \gamma \stackrel{\circ}{\circ}$ ratios were obtained in 118 cases by globin chain $\varrho$ synthesis analysis of practically pure fetal blood $\overrightarrow{\hat{O}}$ samples, as original concentrations or after Ørskov 3 lysis or differential agglutination, and in 76 cases they were calculated by extrapolation using at least three different samples obtained after anti-i agglutination (51 cases) or original placentalç samples with differing fetal red cell percentages (25 cases).

Forty-two fetuses with a $\beta / \gamma$ ratio of 0 and one $\delta$ with 0.005 were presumed to be $\beta$-thalassaemia homozygotes (fig 3).

Since globin chain synthesis analysis at birth $\supset$ was found to be inappropriate for the precise identification of $\beta$-thalassaemia heterozygotes, ${ }^{29}{ }^{30} \mathrm{~N}$ we divided the non-homozygous fetuses into two groups. One included normal and heterozygous $N$ fetuses defined by complete haematological assess- N ment, including $\mathrm{Hb} \mathrm{A}$ and $\mathrm{F}$ determination after the stage of haematological maturity (4 to 12 months 0 after birth), and the other (non-homozygotes) had only globin chain synthesis analysis at birth. Twenty- $\stackrel{?}{?}$ four fetuses, diagnosed as normal at follow-up, 0 had $\beta / \gamma$ globin chain synthesis ratios from 0.049 to $0 \cdot 120$ with a mean of $0 \cdot 086 \pm 0 \cdot 019$. Fifty-four $\stackrel{\vec{Q}}{\stackrel{Q}{Q}}$ fetuses, identified as $\beta$-thalassaemia heterozygotes at $\Phi$ follow-up, had mean $\beta / \gamma$ ratios of $0.046 \pm 0.012 \frac{2}{\sigma}$ 


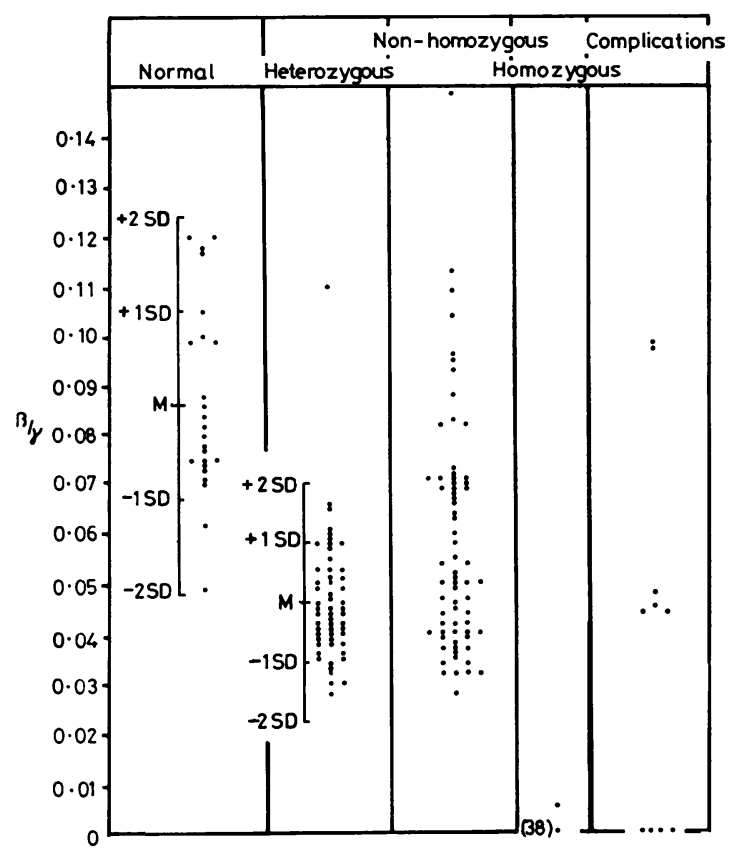

FIG $3 \beta / \gamma$ ratios in fetuses at risk for homozygous $\beta$-thalassaemia. Normal and heterozygous: fetuses in which the genotype was assessed 4-6 months after birth; non-homozygous: fetuses examined only at birth by globin chain synthesis analysis and/or acetate and agar gel electrophoresis; $38=$ number of homozygotes with $a \beta / \gamma$ ratio of 0 .

with a range of $0 \cdot 028-0 \cdot 110$. A statistically significant difference $(p<0.0001)$ between mean $\beta / \gamma$ ratios of normal and $\beta$-thalassaemia heterozygotes was found, with a small overlap of individual values.

The second group (non-homozygotes) showed $\beta / \gamma$ ratios ranging from $0 \cdot 028$ to $0 \cdot 142$. They will be genotyped at follow-up examination. It is worth pointing out that the lowest value found in heterozygous fetuses was $0 \cdot 028$.

HAEMATOLOGICAL AND CLINICAL FOLLOW-UP Of the 43 pregnancies diagnosed as having a $\beta$ thalassaemia homozygous fetus, 37 were terminated on parental request and four aborted spontaneously. After abortion, fetal blood was suitable for analysis in only 12 cases and the absence of $\beta$-chains was confirmed. Two couples, with homozygous $\beta$ thalassaemia fetuses, decided to continue the pregnancy, as one member of each was a devout Catholic. Both these infants developed Cooley's anaemia with haematological findings consistent with homozygous $\beta^{0}$-thalassaemia.

By biosynthetic measurement and/or cellulose
TABLE 6 Haematological follow-up of 148 infants born after antenatal diagnosis

Normal* 24

B-thalassaemia heterozygotes* $\quad 54$

Non-homozygotes $\dagger \quad 68$

Homozygotes $\ddagger$

*With red cell indices, $\mathrm{Hb} \mathrm{A}^{2}$ and $\mathrm{F}$ measurement at 4-6 months.

tUndefined genotype as these infants have not reached the stage of haematological maturity (4-6 months).

‡Diagnosed correctly in utero.

acetate $\mathrm{pH} 8 \cdot 4$ and agar gel $\mathrm{pH} 6 \cdot 2$ electrophoresis on cord blood or venous blood at 1 to 2 days, thalassaemia major was excluded in all the infants diagnosed in utero as non-homozygotes (table 6).

Seventy-eight infants, including all the offspring of pregnancies at risk for $\beta^{+}$-thalassaemia, were followed up to haematological maturity (4 to 6 months). Of these, $30.7 \%$ were normal and $69.3 \%$ were $\beta$-thalassaemia heterozygotes. No misdiagnosis was made (table 6).

\section{Discussion}

This study, concerning a group of 200 pregnancies at risk for $\beta$-thalassaemia, monitored by fetal blood sampling with placentocentesis and globin chain synthesis analysis of fetal blood, shows that antenatal diagnosis of homozygous $\beta$-thalassaemia is feasible and accurate, with acceptably low failure and fetal loss rates, confirming and expanding previous studies. ${ }^{12} 14$ 16-18

Fetal blood sampling by needling in the second trimester has a high degree of success with a failure rate of only $2.5 \%$. Moreover, there was a decline in the failure rate from $3 \%$ in the first series of 100 cases to $2 \%$ in the second 100 cases examined, through the obstetrician gaining experience and the introduction of Ørskov lysis, which allowed successful analysis even with relatively low fetal red blood cell percentages (less than $5 \%$ ). As we have already reported, ${ }^{1617}$ there was a slightly higher success rate in posterior than in anterior placentas, as greater red cell percentages were obtained in the former.

Besides placental aspiration, fetal blood can be obtained by fetoscopy. ${ }^{4151831}$ Both techniques have a high degree of success, ${ }^{15}$ but placental aspiration requires less skill, facilities, and organisation. Therefore, it can be performed in underdeveloped countries where thalassaemia is more prevalent.

The fetal loss rate was $6 \cdot 5 \%$, slightly higher in anterior than in posterior placentas (fig 1). Interestingly, as was seen in the failure rate, the fetal loss rate had a continuous decline from $10 \%$ seen in the 
first 100 consecutive cases to $3 \%$ in the last 100 examined. This too may be partially attributed to the increased experience in fetal blood sampling gained by the obstetrician and partially to the introduction of Ørksov lysis for fetal red cell concentration. In fact, with this technique the number of placental aspirations required have been minimised, because the procedure was stopped as soon as a minimum amount of fetal blood was obtained.

The fetal loss rate of $6.5 \%$ seen in our series is similar to the overall rate of $6.7 \%$ observed in approximately 1100 cases, including ours, studied in several centres around the world up to March 1980 (Alter, 1980, personal communication) and lower than the $9.5 \%$ noted by Matsakis $e^{2} a^{32}$ in a group of 200 cases. In both these series sampling was carried out by needling or fetoscopy.

In our pregnancies fetal losses resulted from early or late intrauterine death and spontaneous abortion. Consistent fetomaternal transfusion was very rare, being observed in $0.5 \%$ of the subjects.

Apart from fetal loss, no major adverse effect of the placentocentesis was seen in the mothers or the babies. A case of hemiplegic cerebral palsy was detected at follow-up, giving an incidence of $0.5 \%$, slightly higher than the $0.25 \%$ figure already noted in a large series of newborns. ${ }^{33}$ It cannot be excluded that this complication resulted from the placental sampling. However, it should be noted that in this pregnancy needling was performed easily and was successful at the first attempt with withdrawal of only two small placental samples.

The risk of physical injury to the fetus is real, as is shown by the placentocentesis needle injury found in three babies. However, from our experience the risk appears slight and the injuries minor. Finally, from the limited data collected to date, it seems that there was no major adverse effect of placentocentesis on child growth and development (unpublished observations).

Both anti-i differential agglutination and Ørskov lysis may result in satisfactory fetal red cell enrichment, as has already been seen. ${ }^{1415}$ Since the availability of high titre anti-i is limited and anti-i differential agglutination is inefficient in samples containing less than $5 \%$ fetal red blood cells, Ørskov lysis could be considered the best method for fetal red cell enrichment. However, at times a satisfactory fetal red blood cell concentration could not be obtained with this method. It is worth noting that the samples in which Ørskov lysis failed could be successfully enriched with anti-i.

The biochemical analysis of fetal blood with globin chain synthesis analysis seems to be extremely accurate. In the pregnancy at risk for sickle cell $/ \beta^{0}$ thalassaemia, both $\beta^{S}$ - and $\beta^{A}$-globin chain synthesis were readily demonstrated allowing a diagnosis of sickle cell trait.

Homozygous $\beta^{0}$-thalassaemia fetuses with no $\beta$-chain synthesis were clearly distinguishable from heterozygous fetuses in which the lowest $\beta / \gamma$ ratio found was $0 \cdot 028$. Globin chain synthesis analysis in cord blood of aborted fetuses, whenever there was suitable blood for analysis, confirmed the absence of $\beta$-chain synthesis. Two cases which continued to term, in which no $\beta$-chain synthesis had been found in the second trimester, developed transfusion-dependent thalassaemia major with haematological findings consistent with homozygous $\beta^{0}$-thalassaemia. It should be noted that the figure of 43 out of 200 fetuses with no $\beta$-chain synthesis is very close to the value of $1: 4$ expected for an inherited recessive disorder.

Finally, no misdiagnosis was made, as shown by the haematological and clinical follow-up study carried out in all cases where the homozygous state was ruled out.

Our experience with $\beta^{+}$-thalassaemia is rather limited, as only one homozygous fetus with a $\beta / \gamma$ ratio of 0.005 was diagnosed in the second trimester. According to Matsakis et al, ${ }^{32}$ it appears that the upper limit for $\mathrm{Hb} \mathrm{A}$ synthesis in fetuses with $\beta^{+}$-thalassaemia major can be clearly separated from the lower limit in fetuses with $\beta^{0}$-thalassaemia trait, as the ambiguous results occurring in $3 \%$ of the cases in his series were clarified by repeating the analysis after 2 to 3 weeks.

From our results it appears that the $\beta$-thalassaemia trait can be identified in the second trimester with a high degree of certainty. In fact, genotype assessment 6 months after birth showed only a slight overlap between normal and $\beta$-thalassaemia heterozygous fetal $\beta / \gamma$ globin chain synthesis ratios.

Several technical problems may cause difficulties in antenatal diagnosis of $\beta$-thalassaemia. Among these is the presence of a $\gamma$ variant comigrating with the $\beta$-chains, as was recently observed in our service, ${ }^{34}$ in which modification of the phosphate gradient allowed us to separate the $\beta$ and $\gamma$ variant chains and thereby diagnose antenatally a normal fetus which was confirmed after birth.

Besides benefit to individual couples, antenatal diagnosis of $\beta$-thalassaemia, when associated with carrier screening of people of child bearing age, has even greater benefits for society. In southern Sardinia, where our service is located, the annual birth rate of $\beta$-thalassaemia homozygotes declined from $1: 213$ live births in 1976 to $1: 296$ in 1978 .

In conclusion, the results presented in this paper show that globin chain synthesis analysis of fetal $\frac{\Omega}{8}$

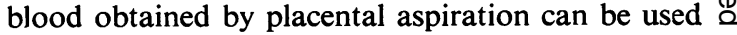
to monitor pregnancies at risk for homozygous 
$\beta$-thalassaemia, as the biochemical analysis was very accurate and the fetal loss rate was found to be acceptably low. However, in order to minimise further the fetal loss rate, our project consists of monitoring pregnancies at risk with fetal blood sampling only when indirect diagnosis by DNA linkage (Bam $\mathrm{HI}$ and/or $\mathrm{G} \gamma-\mathrm{A} \gamma$ polymorphisms) analysis of amniotic fluid cells ${ }^{35}{ }^{36}$ cannot be used.

We would like to thank $\operatorname{Dr} Y$ W Kan for his continuing advice and Rita Loi and Kathleen Stark for their excellent editorial assistance.

This work was supported in part by grants from Assessorato Igiene e Sanità Regione Sarda, CNR subprogetto "Malattie Ereditarie dell'Eritrocita" contract number 80.02252.83 and NIH grant No RO5 HL-24173-03.

\section{References}

1 Hobbins JC, Mahoney MJ. In utero diagnosis of hemoglobinopathies: technic for obtaining fetal blood. $N$ Engl J Med 1974;290:1065-7.

2 Kan YW, Valenti C, Carnazza V, Guidotti R, Rieder RF. Fetal blood sampling in utero. Lancet $1974 ; \mathbf{i}: 79-80$

3 Benzie RJ. Fetoscopy. Mod Med 1975;30:780-3.

4 Rodeck CM, Campbell S. Sampling of pure fetal blood by fetoscopy in second trimester of pregnancy. $\mathrm{Br} \mathrm{Med} \mathrm{J}$ $1978 ;$ ii: 728.

5 Fairweather DVI, Ward RMT, Modell B. Obstetric aspects of mid-trimester fetal blood sampling by needling or fetoscopy. Br J Obstet Gynaecol 1980;87:87-99.

6 Cividalli G, Nathan DG, Kan YW, Santamarina B, Frigoletto F. Relation of beta to gamma synthesis during the first trimester: an approach to prenatal diagnosis of thalassemia. Pediatr Res 1974;8:553-60.

7 Kan YW, Nathan DG, Cividalli G, Frigoletto F. Intrauterine diagnosis of thalassemia. Ann NY Acad Sci $1974 ; 232: 145-51$.

8 Hollemberg MD, Kaback MM, Kazazian HH Jr. Adult hemoglobin synthesis by reticulocytes from the human fetus at midtrimester. Science 1971;174:698-702.

9 Chang H, Modell B, Alter BP, et al. Expression of the $\beta$-thalassemia gene in the first trimester fetus. Proc Natl Acad Sci (USA) 1975;72:3633-7.

10 Kan YW, Golbus MS, Klein P, Dozy AM. Successful application of prenatal diagnosis in a pregnancy at risk for homozygous $\beta$-thalassemia. N Engl J Med 1975;292: 1096-9.

11 Kan YW, Golbus MS, Trecartin RF, Furbetta M, Cao A. Prenatal diagnosis of homozygous $\beta$-thalassaemia. Lancet 1975 ;ii:790-2.

12 Alter BP, Modell B, Fairweather D, et al. Prenatal diagnosis of hemoglobinopathies. A review of 15 cases. $N$ Engl J Med 1976;295:1437-43.

13 Alter BP, Nathan DG. Antenatal diagnosis of hematological disorders-1978. Clin Hematol 1978;7:195-216.

14 Kan YW, Golbus MS, Trecartin F, et al. Prenatal diagnosis of $\beta$-thalassaemia and sickle cell anaemia. Experience with 24 cases. Lancet 1977;i:269-71.

15 Alter BP. Prenatal diagnosis of hemoglobinopathies and other hematologic diseases. J Pediatr 1979;95:501-13.

16 Furbetta M, Angius A, Ximenes A, et al. Prenatal diagnosis of $\beta$-thalassemia: experience with 24 cases. Isr J Med Sci 1978;14:1107-10.

17 Cao A, Furbetta M, Angius A, Ximenes A, Angioni G,
Caminiti F. Prenatal diagnosis of $\beta$-thalassemia: experience with 133 cases and effect of fetal blood sampling on child development. Ann NY Acad Sci 1980;344:165-80.

18 Fairweather DVI, Modell B, Berdukas U, et al. Antenatal diagnosis of thalassaemia major. Br Med J 1978;1:350-3.

19 Kan YW. Prenatal diagnosis of hemoglobin disorders. In: Brown EB, ed. Progress in hematology. Vol X. New York: Grune and Stratton, 1978:91-104.

20 Cao A, Furbetta M, Ximenes A, et al. $\beta$-thalassaemia types in southern Sardinia. J Med Genet 1981;18:196-9.

21 Huisman THJ, Schroeder W, Brodie AN, Mayson SM, Jakway J. Microchromatography of hemoglobins. III. A simplified procedure for the determination of hemoglobin $\mathrm{A}_{2}$. J Lab Clin Med 1975;86:700-2.

22 Kan YW, Schwartz F, Nathan DG. Globin chain synthesis in the $\beta$-thalassemia syndromes. J Clin Invest $1968 ; 47: 2515-22$.

23 Kleihauer E, Braum H, Betke $\mathrm{K}$. Demonstration von fetalem hämoglobin in den erythrocyten eines blutansstrichs. Klin Wochenschr 1957;35:637-8.

24 Boyer SH, Noyes AN, Boyer LM. Enrichment of erythrocytes of fetal origin from adult-fetal blood mixtures via selective hemolysis of adult blood cells: an aid to antenatal diagnosis of hemoglobinopathies. Blood 1976;47: 883-97.

25 Alter BP, Metzger JB, Yock PG, Rothchild SB, Dover GJ. Selective hemolysis of adult red blood cells: an aid to prenatal diagnosis of hemoglobinopathies. Blood 1979; 53:279-87.

26 Furbetta M, Angius A, Ximenes A, et al. Prenatal diagnosis of $\beta$-thalassaemia by fetal red cell enrichment with $\mathrm{NH}_{4} \mathrm{Cl}-\mathrm{NH}_{4} \mathrm{HCO}_{3}$ differential lysis of maternal cells. Br J Haematol 1980;44:441-50.

27 Furbetta $\mathrm{M}$, Valenti C, Ximenes A, et al. Prenatal diagnosis of $\beta$-thalassaemia by fetal red cell concentration with anti-AB serum. J Med Genet 1979;16:366-8.

28 Pembrey ME, McWade P, Weatherall DJ. Reliable routine estimation of small amount of foetal haemoglogin by alkali denaturation. J Clin Pathol 1972;25:738-40.

29 Alter BP. Beta thalassaemia trait: imprecision of diagnosis at birth. Br J Haematol 1978;38:323-7.

30 Furbetta M, Angius A, Tuveri T, et al. Diagnosis of the $\beta^{0}$-thalassemia trait at birth. Hemoglobin $1981 ; 3: 217-29$.

31 Rodeck CH. Fetoscopy guided by real time ultrasound for pure fetal blood samples, fetal skin samples and examination of the fetus in utero. Br J Obstet Gynaecol $1980 ; 87: 449-51$

32 Matsakis M, Berdukas VA, Angostiniotis M, et al. Haematological aspects of antenatal diagnosis for thalassaemia in Britain. $\mathrm{Br} \mathrm{J} \mathrm{Haematol} \mathrm{(in} \mathrm{press).}$

33 Hagberg B, Hagberg G, Olow I. The changing panorama of cerebral palsy in Sweden 1954-1970. Acta Paediatr Scand $1975 ; 64: 187-92$.

34 Furbetta M, Angius A, Ximenes A, et al. Difficulties in antenatal diagnosis of inherited haemoglobinopathies: $\gamma$-chain variants. Br J Haematol 1981 ;41:319-23.

35 Kan YW, Lee KY, Furbetta M, Angius A, Cao A. Polymorphism of DNA sequence in the $\beta$-globin gene region. Application to prenatal diagnosis of $\beta^{0}$-thalassemia in Sardinia. $N$ Engl J Med 1980;185-8.

36 Little PFR, Annison G, Darling S, Williamson R, Cambe L, Modell B. Model for antenatal diagnosis of $\beta$-thalassaemia and other monogenic disorders by molecular analysis of linked DNA polymorphism. Nature 1980; 144-7.

Requests for reprints to Professor A Cao, 2a Clinica Pediatrica, Università Studi Cagliari, Via Porcell 1, (C/P 251), 09100 Cagliari, Sardinia, Italy. 